\title{
Islamizing Egypt? Testing the limits of Gramscian counterhegemonic strategies
}

\author{
Hazem Kandil
}

Published online: 14 January 2011

(C) The Author(s) 2011. This article is published with open access at Springerlink.com

\begin{abstract}
This article evaluates the political effectiveness of the Gramscian-style counterhegemonic strategy employed by the leading Islamist movement in Egypt. The article analyzes, historically and comparatively, the unfolding of this strategy during the period from 1982 to 2007, emphasizing how its success triggered heightened state repression, which ultimately prevented Islamists from capitalizing politically on their growing cultural power. The coercive capacity of modern states, as this article demonstrates, can preserve a regime's political domination long after it has lost its cultural hegemony. The empirical evidence derived from the Islamist experience in Egypt supports theoretical claims that go beyond the Egyptian case: namely, it exposes the limits of the narrow cultural reading of Gramsci that has become commonplace over the years.
\end{abstract}

Keywords Islamism $\cdot$ State coercion $\cdot$ Authoritarianism $\cdot$ Gramsci

A resistance too long prolonged in a besieged camp is demoralizing in itself. It implies suffering, fatigue, loss of rest, illness and continual presence not of the acute danger which tempers but the chronic danger which destroys.

Karl Marx, Eastern Question, 1855

Can a radical movement come to power through a culture-based strategy? A number of revolution theorists have claimed that cultural mobilization fuels popular revolts (Walzer 1965; Hunt 1984; Sewell 1995; Selbin 1997). Others have maintained that while structural shifts remain the key determinants of revolution, cultural idioms play a strategic role during the revolutionary process itself (Goldstone 1991;

H. Kandil ( $\bowtie)$

Department of Sociology, University of California, Los Angeles, CA, USA

e-mail: hkandil@ucla.edu 
Moaddel 1993; Skocpol 1994; Burns 1996; Foran 2005). And all sociologists of revolution would probably agree with Huntington (1968, p. 264) that changing the "dominant values and myths" of a society is an integral part of what constitutes a revolutionary transformation. As a cultural critic, political theorist, and revolutionary strategist, Antonio Gramsci is certainly one of the primary authorities to weigh in on this debate. Although the relationship between culture and revolution has been explored in the works of Lukács, Adorno, Horkheimer, and other Western Marxists, Gramsci's exposition of the organic link between cultural and political change was the clearest and most elaborate. He was the first to point out that because a ruling regime legitimizes its domination through cultural hegemony, ${ }^{1}$ its overthrow must begin by countering this hegemony. The aim of a counterhegemonic strategy is to foster contradictions between the worldview of the rulers and that of the ruled in order to antagonize "huge masses" and mobilize them to "put forward demands which taken together ... add up to a revolution” (1971, pp. 242, 210).

But although counterhegemony for Gramsci was meant to spark off a violent confrontation with the regime, the "normally accepted view" after his death reduced political struggle to counter-culture campaigns (Joseph 2002, p. 31). This interpretation not only "diluted Gramsci's critical bite," but it also "wandered too far away from Gramsci's original meaning of hegemony." The advocates of this cultural reading were as diverse as structural Marxists, Frankfurt School theorists, post-structuralists, and postmodernists. While each school tackled cultural hegemony differently, they all contributed to diverting attention away from the role of state coercion (Litowitz 2001, pp. 550, 531-535). Under their intellectual impact, Eurocommunists popularized a version of Gramsci that called for "a gradual capture of the institutions of civil society as an alternative to a full confrontation with the power of the state" (Joseph 2002, p. 40). This version was also well received on the other side of the Atlantic, where Gramscian strategists "accentuated the elements of consent, persuasion, and opinion formation while de-emphasizing elements such as force, coercion, violence and domination." Gramsci was thus reduced to "a liberal (in the American sense) or a social democrat (in the European sense)" (Fontana 2009, pp. 94-95).

Yet the most striking exponents of this reading of Gramsci were Islamist movements. Around the same time when Gramsci was penning down his Prison Notebooks (late 1920s and early 1930s), Hassan al-Banna, founder of al-Ikhwan alMuslimin (Muslim Brothers), the world's first and largest ${ }^{2}$ Islamist movement, expressed the need to change al-rouh al-'am alazi uhaimin (the hegemonic public spirit) in Muslim countries before Islamists can target power (Al-Banna 1948, p.

\footnotetext{
${ }^{1}$ While Gramsci today has become "synonymous with the concept of hegemony" (Joseph 2002, p. 19), the term dates back to ancient Greeks. Herodotus and Thucydides used it to describe the leader of an alliance of city-states (such as Athens in the Delian League). For Plato, Aristotle, and Isocrates, hegemony signified a method of government that synthesizes power and knowledge. In international relations, the term referred to a state's power over others. In socialist discourse, it was employed in late nineteenth- and early twentieth-century debates among Russian socialists (Plekhanov, Axelrod, Lenin, and Trotsky) to describe the leading role of the proletariat vis-à-vis peasants (Fontana 2008, pp. 80-84; Anderson 1976, pp. 15-17). Gramsci expanded the socialist use of the concept from proletarian leadership "to political leadership more generally and to society as a whole" (Joseph 2002, p. 28).

2 'Abd al-Hameed al-Ghazali, the political advisor to al-Ikhwan's Supreme Guide, declared that al-Ikhwan members exceed 15 million in Egypt alone (Salah 2009: Al-Masry Al-Youm, October 29, 2009).
} 
113). From that time on, with the obvious differences between Islamists and leftists notwithstanding, strategies of cultural transformation have become central to most Islamist movements around the world. The ultimate aim of Islamist politics, Hefner wrote, was not to confront state rulers directly, but to create "a Muslim 'civil society" capable of counterbalancing the power of the state" (2001, p. 15). Islamists drew on religious symbols and practices to alienate the masses from their secular rulers and turn them into political dissidents (Wiktorowicz 2004, pp. 2-3; Burke and Lapidus 1988, pp. 15-19). Islamists shared Gramsci's belief that replacing the rulers' hegemony with their own is a necessary first step to winning the political struggle.

Clearly, Islamists were not deliberately embracing a strategy formulated by an Italian Marxist. They formally ascribed their strategy to the experience of Prophet Muhammad, who first established an alternative way of being and doing before reaching for political power. So why examine this Islamist strategy from a Gramscian perspective? First, the Prophet's strategy was carried out in a society devoid of parties, syndicates, unions, mass media, courts, standing armies, and police - in short, the modern state. ${ }^{3}$ Because these modern institutions structure the field of Islamist struggle today, we need a modern theoretical approach to study it. Second, because the Islamist strategy paralleled the cultural version of Gramsci's doctrine, analyzing how this strategy unfolded provides an opportunity to observe its limitations. So while a Gramscian framework helps us make sense of what Islamists were trying to achieve, the empirical case itself serves to evaluate the efficacy of an exclusively cultural reading of Gramsci.

A related question is whether we can apply Gramscian concepts to non-class struggles. A few scholars have argued that in fact we should. Morton warned that confining Gramsci to class-based politics keeps us "blinkered to the variety of identities" that Gramsci understood to motivate political action (2007, p. 211). Fiori contended that Gramsci's preoccupation with class struggle should not eclipse his more general theoretical contribution: namely, "how thinking can lead to actions, how a thought can make peoples' hands move, and how and in what sense ideas themselves may be actions" (1970, p. 93). Fontana attributed Gramsci's continued relevance in a post-socialist world to the fact that his theoretical formulas were applicable to situations other than those that inspired them (2009, p. 81). Similarly, Howson and Smith argued that the leitmotif of Gramsci's intellectual project was how any subordinated group could achieve "ethico-political hegemony" (2008, p. 12). Gramsci's work was essentially a reassertion of the significance of "moral and intellectual leadership" (Howson 2008, p. 25). Not surprisingly, Billings believed that Gramsci's theorization of cultural struggle offered unique sociological insights to situations where religion is the vehicle for opposition (1990, pp. 6, 27). Counterhegemonic strategies were preeminently "moral and intellectual battles" that used "ideology, [and] religion" to pave the ground for a new political reality (Fontana 2008, pp. 93-96). That explains why scholars such as Butko (2004) and Bayat (2007) employed Gramscian concepts in their study of Islamist movements.

\footnotetext{
$\overline{3}$ Islamists dismiss this difference, claiming that if they succeed in bringing society back to religion, God will reward them with political power. This conviction relieves Islamists from political accountability; if they fail to reach power, it is because society is not yet sufficiently religious, and the solution is to devote more time and resources to cultural reform rather than reconsidering the efficacy of their strategy.
} 
So far, however, works on Islamism suggest that Islamists' increasing cultural hegemony is bound to yield considerable political gains (Eickelman and Piscatori 1996; Abdo 2000; Rubin 2002; Wickham 2004; Wiktorowicz 2004; Butko 2004; Mahmood 2005; Bayat 2007). But while these works shed light on how Islamists strategize and operate, they do not explain why Islamists have had so little political success despite their increasing hegemony. ${ }^{4}$ In this article, I build on these works to explore the limits of counterhegemonic strategies through an in-depth analysis of the power struggle between al-Ikhwan and Mubarak's regime. From 1982 to 2007, Islamists successfully undermined the rulers' cultural hegemony in the hopes that the masses would imminently rise against the regime. Instead, escalating state repression prevented Islamists from capitalizing politically on their cultural hegemony. Drawing on the Egyptian experience, I argue that the likely outcome of culturally successful counterhegemonic strategies is heightened repression, and thus failure to take power. For while these strategies enable an opposition movement to unite society culturally against the regime, they do not help it wrest effective control of the state's coercive power. My analysis emphasizes how control over the organs of repression remains the final arbiter of political power-a conclusion that can be generalized beyond the Egyptian case.

I begin the article with an overview of Gramsci's theoretical framework, followed by a discussion of Islamism, Islamization, and the historical development of the power struggle between al-Ikhwan and the Egyptian regime. I conclude my case-study analysis with an assessment of the limits of culture-oriented counterhegemonic strategies.

\section{Theoretical framework}

Following years of radical activism in Italy, Gramsci ended up in prison and saw his country slide to fascism. To explain the triumph of fascism over both democracy and socialism in Italy, Gramsci spent his prison years theorizing the failure of Italy's two revolutions: the liberal revolution born out of the Risorgimento, and the aborted socialist revolution of the biennio rosso. Gramsci believed that these revolutions failed because they were not sufficiently grounded in the values and practices of the populace. In the wake of modernity and the breakdown of traditional communal ties, the masses have become a political force to be reckoned with (Fontana 2009, pp. 80, 92). Winning them over, Gramsci argued, required extending the Marxist concept of struggle beyond the economic sphere to the realm of ideas and morality (Howson 2008, p. 27).

Gramsci expected opposition movements to build on these reflections, to wage a long-term cultural war against their rulers rather than rushing into an ill-prepared conflict over state power (Fiori 1970, p. 203). Gramsci defined culture in an article published in Il Grido del Popolo, on January 29, 1916, as "the disciplining of one's inner self; the mastery of one's personality; the attainment of higher awareness,

\footnotetext{
4 The few works that did tackle the political limitations of Islamists' strategies (such as Kepel 2002; Zeidan in Rubin 2003; and Al-'Awa 2006) focused on the failure of militant Islamist insurgents rather than the non-militant movements, which are the subject of this study.
} 
through which we can come to understand our value and place within history, our proper function in life." He therefore required opposition movements to produce new ways of thinking and acting on the individual level. Citing the Enlightenment's influence on the French Revolution, Gramsci highlighted how "every revolution" is usually "preceded by a long process of intense critical activity, of new cultural insight and the spread of ideas through groups of men initially resistant to them" (1994, p. 10).

Before introducing the concept of counterhegemony, Gramsci had to walk his readers through three important distinctions: (1) between political and civil societies, (2) between East and West, and (3) between "war of maneuver" and "war of position." The first distinction can be derived from Gramsci's definition of the state as: "political society + civil society, in other words hegemony armored with coercion" (1971, p. 263). ${ }^{5}$ Political society, in this formula, consisted primarily of the organs of coercion, while civil society included all those institutions that disseminate worldviews and cultivate popular consent. In this scheme, civil society was distinguishable enough from political society that it "can be independently conquered" by an opposition movement, yet it was linked closely enough to political society so that "its conquest will be guaranteed to have political ramifications." Thus the two were interlocked in "circular interaction within an organic whole," which is the state (Lears 1985, p. 570).

The second distinction followed from Gramsci's assertion that the Russian Revolution was the last occurrence of its kind because the relationship between political and civil societies had been permanently altered. In Russia, Gramsci's archetype for the East, political society was everything, whereas civil society was "primordial and gelatinous." But in Western Europe, civil society developed into a "powerful system of fortresses and earthworks" that supported political society. Using military analogy, Gramsci described political institutions in the West as the "outer perimeter" of the enemy's defense system and civil society as its core. So while an opposition movement in the East could have achieved social transformation through its control of political power, movements in the West must control civil society first (1971, pp. 233, 12). ${ }^{6}$

This is where the third distinction sets in. Opposition strategists must shift from "wars of maneuver" to "wars of position": that is, from forceful assaults against political institutions to cultural struggles within civil society (Gramsci 1971, pp. 233-239). Gramsci argued that the modern state relied less on coercion than on the "acceptance by the ruled of a 'conception of the world' which belongs to the rulers" (Fiori 1970, p. 238). Through the "[e]ducative and formative" organs of the state, rulers caused their subjects not only to accept, but also to internalize the ruling

\footnotetext{
${ }^{5}$ Anderson noted that Gramsci also discussed the State in contrast with civil society and as identical to civil society (1976, pp. 12-15). The abovementioned formulation, however, is the one Gramsci used most consistently, especially in articulating his notion of counterhegemony.

${ }^{6}$ Of course Gramsci was not only referring to the liberal West. During his lifetime, Western Europe was ripe with authoritarian regimes, such as fascist Italy and the Weimar Republic. He thus employed the term "West" to describe modern centralized states in general. His aim was to highlight the absence of social intermediaries in undeveloped societies, when compared to modern states with their "tightly woven network of ... institutions," which rendered social revolutions a "political and psychological impossibility" (Jones 2006, p. 31).
} 
worldview (Gramsci 1971, p. 242). By securing consensus within civil society, modern rulers became hegemonic (Adamson 1980, p. 171).

With these three distinctions in mind, Gramsci described hegemony as "the whole range of values, attitudes, beliefs, cultural norms, legal precepts [that are] deeplyembedded in the fabric of social relations." To challenge hegemonic rulers directly is to set oneself against the "defining motif" of people's everyday life, to contradict what they regard as "common sense" (Boggs 1984, pp. 160-164). The ruling worldview is thus protected by "parents, preachers, teachers, journalists, literati ... entertainment promoters, popular musicians, sports figures;" in brief, all those involved in shaping social beliefs and defining the boundaries of "common-sense reality" (Lears 1985, p. 572). Even subaltern groups participate in safeguarding the established order; through perpetuating the hegemonic worldview, they reproduce their own subordination (Jones 2006, p. 41).

How could a revolution occur under these conditions? In Gramsci's view, radical change is the product of a "steady ascension of a mass-based, educated, and organized collective will in which the final seizure of power is merely the climatic act" (Adamson 1980, p. 45). Opposition forces should begin by exposing the inherent contradictions in the hegemonic worldview in the hope that "stripping away [these] protective hegemonic facades [will render the] exploitative and repressive nature of the system ... less and less opaque" (Boggs 1984, p. 165). But in tandem with undermining the hegemonic worldview, opposition movements must also build an alternative hegemony (Butko 2004, p. 43). Disrupting the "false and irrational world" of the existing order is insufficient as long as the opposition does not produce a "new universe of belief systems, cultural values, and social relations" (Boggs 1984, p. 166). Gramsci therefore proposed that opposition movements should create a situation where "civil society and political society enter into contradiction," a situation where the rulers, though still politically dominant, are no longer culturally hegemonic, and the opposition, though still away from power, enjoys considerable hegemony within civil society. Only then could an opposition movement make its bid for power (Adamson 1980, pp. 171, 215-219, 225).

This struggle to rupture the symbiotic relationship between civil and political societies through transforming popular consciousness constituted what Gramsci described as "counterhegemony" or "war of position": a cultural struggle waged within civil society using platforms suitable for "cultural transmission," such as parliament, educative and religious institutions, professional associations, the media, and the courts (Boggs 1984, pp. 160-161). To implement a counterhegemonic strategy, a movement needs to (1) develop an ideology with the potential of winning popular support, (2) build a diffuse organizational structure that could penetrate all social spheres, and (3) judge the "precise moment when the 'war of position' has reached its climax and must necessarily be transformed into a "war of movement (maneuver)"' (Butko 2004, pp. 48-51).

This last element is crucial. Gramsci's approach to politics was deeply influenced by Machiavelli's “dynamic of force and consent” (Joseph 2002, pp. 21-22). Gramsci understood the very nature of political power from a "dual perspective ... corresponding to the dual nature of Machiavelli's Centaur-half-animal and halfhuman." In The Prince, the Centaur embodied the synthesis of the two fundamental levels of power: "of force and of consent, authority and hegemony, violence and 
civilization" (Gramsci 1971, pp. 169-170). What that meant was that for Gramsci both levels of the dyad were essential: "Hegemony never replaces, though it may veil, dictatorship, in the same way consent never replaces force." The generation of consent is only a "precondition for the capture of state power" through the "use of force" (Fontana 2009, p. 94). Another source of inspiration from The Prince was Machiavelli's solemn reflection that "all armed Prophets have been victorious, and all unarmed Prophets have been destroyed" (Machiavelli [1532] 2004, p. 26). ${ }^{7}$ This was where Gramsci derived his conception of the polarity of leadership and domination (Fontana 2008, p. 87); that a movement's "intellectual and moral leadership" vis-à-vis it social allies must be supplemented by its ability to "'liquidate' or to subdue ... with armed force" those who oppose it (Gramsci 1971, pp. 57-58).

If a movement failed to identify the point where the ruling regime was no longer hegemonic and followed that with a frontal attack on political institutions then it would remain stuck endlessly in reproducing counterhegemony. For Gramsci, the paramount aim of a counterhegemonic strategy was to prepare the ground culturally for this violent assault (Butko 2004, pp. 56-57). In an article entitled "Why We Need a Cultural Association?" (published in Avanti on December 18, 1917), he explained that "educating and mentally priming" opposition members was meant to ensure "immediate, effective, deep-rooted consensus ... for action"(1994, p. 37). The only reason why an opposition movement needed to form a "homogenous, compact, and self-aware" social force was to be able to "put it into the [fighting] field when it is judged that a situation is favorable" (Gramsci 2000, p. 209). To summarize: "For Gramsci, consent and force nearly always coexist" (Lears 1985, p. 568).

Although Gramsci's work in general became a "terrain for a constant war of positions between different interpreters," this last element of Gramsci's strategic doctrine was the one most frequently misinterpreted (Joseph 2002, p. 19). It might be because some mistakenly understood Gramsci's force/consent polarities as distinct phases in a two-step power struggle rather than simply analytical categories (Fontana 2009, p. 95). Gramsci himself anticipated this problem, expecting some to "reduce the theory of the 'dual perspective' to ... two forms of 'immediacy' which succeed each other mechanically in time" (Gramsci 1971, p. 170). But because interpretations should not be divorced from the context within which they are produced, we ought to consider how environmental factors favored this exclusively cultural reading. In democracies, where opposition is allowed and coercion rarely used, counterhegemonic movements had reason to believe that cultural transformation could provide them with a secure political footing before a state-led coercive backlash ensues. Although the situation under authoritarianism is reversed, the same result obtained; the non-confrontational and soothingly gradual nature of cultural opposition was particularly appealing to movements that operated in settings where state violence was frequent and unrestrained. This was certainly the case in Egypt.

\footnotetext{
${ }^{7}$ Machiavelli was quite explicit on the fact that: "Between the armed and unarmed man no proportion holds, and it is contrary to reason to expect that the armed man should voluntarily submit to him who is unarmed, or that the unarmed man should stand secure among armed retainers" (Machiavelli [1532] 2004, p. 69).
} 


\section{Counterhegemony and repression in Egypt}

Gramsci believed that ideologies are important tools in counterhegemonic strategies because - like religion - they provide "a concrete fantasy which acts on a dispersed and shattered people to arouse and organize its collective will" (1971, pp. 125-126). In his view, interpreting religion in a way that proposed "a unity of faith between a conception of the world and a corresponding norm of conduct" should properly be called an "ideology', or even frankly 'politics" (1971, p. 326). So from a Gramscian perspective Islamism can be defined first and foremost as a political ideology.

Islamism holds that Muslim rulers are religiously obliged to govern according to Islamic teachings. Islamism only crystallized as an ideology in the late nineteenth century: earlier it was simply taken for granted that Muslim rulers must uphold Islamic law and values. Throughout Islamic history, impious leaders, even nonMuslim invaders, had to pretend at least that they were ruling in accordance with Islam. It was only since the 1830 s that Muslim rulers not only abandoned this obligation, but also spearheaded efforts to reorganize their societies according to Western secular values - which they claimed were compatible with Islam. The call to bring society and its rulers back to Islam first appeared in the writings of Jamal alDin al-Afghani (d. 1897) and Rashid Rida (d. 1935). ${ }^{8}$ But it was not until the collapse of the last pan-Islamic political organization (the Caliphate) in 1924 that Islamists organized politically. In 1928, al-Ikhwan became the first embodiment of Islamism. This was a crucial step because, as Gramsci proclaimed, ideologies are hopelessly ineffective until they are represented by a strong movement - a Modern Prince - that "revolutionizes the whole system of intellectual and moral relations ... [and] takes the place of the divinity" in men's consciousness (1971, pp. 132-133).

In line with Gramsci's doctrine, al-Ikhwan did not target political power directly. Its declared goal was to reform the Egyptian ruling elite. Al-Ikhwan's most venerated document is the collection of letters (al-rasa'il) directed by its leader to the rulers exhorting them to adhere to Islam. But because al-Ikhwan believed that colonialism played an important role in maintaining secularism, it also got involved in resisting British colonialism, causing the government - under British pressure - to outlaw the organization and assassinate its charismatic leader. Seeing no prospect in reforming the increasingly westernized ancien régime, al-Ikhwan turned against it. In one of al-Banna's last letters, he declared that it would be "a crime for Islamic reformers not to seize executive power from the hands of those who violate Islam" (Al-Banna 1948, p. 201). Al-Ikhwan supported the 1952 coup $^{9}$ with the expectation that the new regime would adopt Islamism as state ideology (Al-'Erian 2009, pp. 2-3). Nasser, however, opted for a new "eclectic ideology, comprising a mixture of Egyptian nationalism, socialism and Arabism” (Vatikiotis 1978, p. 195).

\footnotetext{
${ }^{8}$ The link between the two was Muhammad 'Abduh, a student of the former and teacher of the latter. But because "Abduh was in favor of modernizing Muslim society along Western lines, he is not considered one of the intellectual forces behind Islamism.

${ }^{9}$ The relationship between al-Ikhwan and the Free Officers is one of the unsolved puzzles in Egypt's modern history. Historical evidence that the Free Officers' evolved out of al-Ikhwan's secret wing in the army (Gohar 1976; Abdel Raouf 1989) has been categorically denied by many of those involved in the coup.
} 
The Islamist decision to target state power-in Egypt and many similar cases (including, Turkey, Iran, Indonesia) — was therefore the product of two fundamental developments that came together in the second half of the twentieth century. First, under the influence of the then prevalent modernization paradigm, the new nationalist regimes regarded religion as an obstacle to progress, and therefore subjected their Muslim societies to a more aggressive wave of secularization than the one they had experienced under colonial ruler. Second, by way of consolidating power and implementing their ambitious modernization projects, nationalist leaders created all-powerful states capable of penetrating society and directing every aspect of social life-including religion. ${ }^{10}$ In the Egyptian case:

[New state institutions guaranteed the regime's] total control of the armed forces ... the neutralization and eventual destruction of other existing loci of political power - the monarchy, political parties, senior officials, land-owning, financial, industrial and commercial members of the old ruling class ... the control of education, the media, professional syndicates, trade unions, the rural structures in the countryside, the religious institutions and orders, the administration and bureaucracy, eventually, the whole society (Vatikiotis 1978, p. 127).

Islamists realized that if they were to fulfill their goals, they would have to take over this powerful institution: the modern state. The state, however, was not only a tempting target, but it was also a formidable one. Nationalists developed an entrenched military-security apparatus to repress potential rivals. As soon as al-Ikhwan targeted state power, it was effectively dismantled and almost all of its members were detained; they remained in prison for the better part of 1954-1974 (Vatikiotis 1978, p. 135).

In prison, many Islamists felt justified to meet force by force. Sayyid Qutb, a leading Ikhwan figure, was the first to articulate this view. His ideas gained currency among disillusioned Islamists who, after two decades of confinement and torture, were released by Sadat (Nasser's successor) to counter communist trends among students and workers. Many broke off from al-Ikhwan and formed militant groups; the leading two (al-Jihad and al-Jama'a al-Islamiya) eventually assassinated Sadat in 1981(Kepel 1984).

The years from 1974 to 1981 were marked by influx and confusion for al-Ikhwan. The movement's first order of business upon leaving prison was to reestablish its supremacy among Islamist activists and incorporate renegade groups. Gramsci alluded to this phase in the lives of heavily repressed opposition movements, a phase when movement leaders must devote all efforts to overcome "fragmentation, disaggregation, incoherence, and disorganization" (Fontana 2009, p. 85). Al-Ikhwan succeeded in recruiting and "rehabilitating" many of the militant leaders (notably, 'Abd al-Mon'iem Abou al-Fotouh, 'Essam al-'Erian, and Abou al-'Ela Madi) and contracted the support of those who preferred to work independently after renouncing violence (like Muntasir al-Zayat). Remaining militants were smashed

\footnotetext{
${ }^{10}$ In 1955, Egypt abolished autonomous shari ' $a$ courts and brought all mosques under the control of the new Ministry of Religious Endowments. In 1961, an administrative law transformed al-Azhar (Egypt's leading religious institution) into "an arm of the state." The state also created a host of public religious agencies to counterweight al-Azhar, notably the High Council on Islamic Affairs (Abdo 2000, p. 51).
} 
by the state following Sadat's assassination; more than forty thousand were detained and the rest fled to Afghanistan (Kepel 2002).

During this period of change and uncertainty, we cannot discern a meaningful pattern of interactions between al-Ikhwan and the regime. But by 1982 a tacit deal was concluded between the two. As small and dispersed as the militants were, they still represented an uncalled-for strain on the state's coercive organs - especially after some returnees from Afghanistan initiated a minor insurgency from 1992 to 1997. Thus, Mubarak agreed to concede limited public space for al-Ikhwan to counter Islamist militancy (Price 1999, pp. 45-46). The formula was simple: al-Ikhwan should focus on promoting moderate Islamism and stay out of politics (Al-'Anani 2009, p. 2). It was during this period that al-Ikhwan launched its counterhegemonic campaign. But it was also during that same time that Egypt completed its transformation from a progressive military-dominated regime to a closed authoritarian police state. In other words, only under Mubarak did both al-Ikhwan's influence in society and the regime's control over it consolidate; it was only then that identifiable strategies began to materialize.

\section{The Islamist counterhegemonic strategy: worldview and structure}

From the beginning, al-Ikhwan decided not to challenge the regime directly. It was not just the memory of two decades in prison, but it was also crude political reality: the regime's highly effective military-security apparatus allowed very little space for maneuver. Islamists had to place their faith in a long-term counterhegemonic strategy within the approved margins. The hope was that a cultural conquest of civil society by a solid "ideological community" would undermine the regime's legitimacy and weaken it politically (Bayat 2007, p. 8). Thus began an extensive "Islamization" strategy, that is: an Islamist counterhegemonic strategy aimed at replacing secular values and practices with Islamic ones. Islamization consisted of two components: (1) generating a worldview that prescribes for Muslims how to think and act, and (2) disseminating this worldview through various socialization structures. In this section, I first discuss how Islamists articulated this new worldview before turning to their strategy for disseminating it.

Gramsci asserted that a subordinated group could not aspire to become hegemonic without first producing a "countervailing conception of the world in opposition to the prevailing one." This alternative worldview must achieve three goals: First, it should produce a new type of "personality," basically its own human embodiment (Fontana 2009, p. 90). In an article published on January 29, 1916 in Il Grido del Popolo, Gramsci emphasized that forming new personalities capable of acting in history is the primary task of subaltern groups (2000, p. 59). But trying to create a more committed type of Muslim personality in a country where over $90 \%$ of the population thought of themselves as already being good enough Muslims was a delicate undertaking. ${ }^{11}$

\footnotetext{
${ }^{11}$ In a report published in October 2009, PEW research center in Washington reported that Muslims represent $94.6 \%$ of Egyptians. The World Values Survey conducted in 2007 stated that of the 65 societies surveyed, "Egyptians were found to be the most pious, with 98\% declaring their religiosity" (Bayat 2007, p. 147).
} 
Second, a counterhegemonic worldview should expose the contradictions between the views of the rulers and those of the ruled in order to diminish the former's legitimacy and force it to reveal its ugly face- the iron fist hidden beneath the silk veil of consensus. The counterhegemonic movement can then mobilize the disillusioned population that finally becomes aware of the fact that it has not been living in a consensual state (Howson and Smith 2008, p. 6; Gramsci 1971, p. 210). Again, exposing the contradictions in the regime's treatment of Islam was difficult to achieve in Egypt because the regime propagated the view that Islam not only allowed for the separation between religion and state, but also encouraged it to protect religion from the mire of politics. Moreover, to protect its legitimacy from those who might accuse it of being anti-Islamic, the regime created an environment where secularism and Islam coexisted: legal codes were partly inspired by shari' $a,{ }^{12}$ secular and Islamic institutions were licensed, secular and Islamic intellectuals appeared in public media, and regime officials attended both secular and Islamic festivals.

Third, an alternative conception of the world should forge a unified "nationalpopular collective will" (Howson and Smith 2008, p. 12). Forming "social alliances" that united all subordinated groups against the regime was central to Gramsci (Fontana 2009, pp. 85-86). Although al-Ikhwan coined an attractive alliancebuilding maxim, "Let us build on what unites us and forgive what divides us" (Al'Erian 2009, p. 3), it was aware of the painful truth that most subaltern groups in Egypt were either secular (leftist workers and peasants, and liberal activists) or deeply hostile to Islamism (feminists and non-Muslims).

So how did Islamists formulate an effective counterhegemonic worldview despite these challenges? To start with, Islamists framed their message as a $d a$ ' $w a$ (call) to return to the concept of shumuliyat al-Islam (comprehensiveness of Islam). AlIkhwan activists commended Egyptians for their religious observance, but reminded them gently that Islamic obligations involved more than worship. Islam was a comprehensive system that governed all aspects of social life. Good Muslims must therefore reject secular ideas and institutions and reestablish their polity according to Islam (Al-Banna 1948, p. 17). The call to re-Islamize society propelled Egyptians to inspect their religiosity for a possible discrepancy between what they believed they were (devout Muslims) and what they might actually be (violators of Islam). This was a Gramscian strategy par excellence. Gramsci held that counterhegemonic movements must push their audience to reflect over the "contrast between [their] thought and action ... the [artificial] coexistence of two conceptions of the world, one affirmed by words and the other displayed in effective action" (Gramsci 1971, pp. 326-327). Al-Ikhwan intensified this suspicion, describing the faith of average Muslims as "sedated, [and] dormant" (Al-Banna 1948, p. 15). Muslims who wanted to overcome this dissonance between belief and action had to carry over their religiosity to the public sphere; they had to translate their faith into sociopolitical activism. In time, Islamization succeeded in producing the multazim (committed) Muslim personality, one who is entirely devoted to making Islamism hegemonic.

\footnotetext{
12 The state supported an amendment to the Second Article of the 1971 Constitution proclaiming that Islam is the source of legislation. But it then neglected the review of existing laws to make sure they correspond with shari'ah.
} 
But al-Ikhwan also had to reveal to Egyptians the historical origins of their "erroneous" perception of Islam as a religion that admits separation between private belief and public practice. In other words, it had to help its audience come to terms with why they had initially subscribed to the ruling secular worldview despite their religiosity. As Gramsci argued:

Self-deception can be an adequate explanation for a few individuals ... but it is not adequate when the contrast occurs in the life of the great masses.... It signifies that the social group in question may indeed have its own conception of the world, even if only embryonic; a conception which manifests itself in action, but occasionally and in flashes.... But this same group has, for reasons of submission and intellectual subordination, adopted a conception which is not its own but is borrowed from another group (1971, pp. 326-327).

It was the Westernized regime, claimed al-Ikhwan. Movement historians (like Raghib al-Sirgani, 'Abbas al-Sisi, and Anwar al-Gindi) wrote extensively on how the rulers played into the hands of the West by accepting that secularism was a prerequisite for modernization, and how they instilled this fallacy into the minds of their citizens through education and propaganda. By implicating the regime in promoting a distorted Western-influenced version of Islam, Islamists not only undermined the credibility of the ruling worldview, but also transformed rulers into practical obstacles to those who wanted to live a good Muslim life.

The most difficult task for al-Ikhwan, however, was to attract non-Islamist subaltern groups (leftist, liberal, and feminist opposition) to their counterhegemonic worldview. That is why the Islamist worldview was articulated, de-articulated, and reconstituted several times to broaden its appeal (Shukrallah 1989, p. 91). For example, they incorporated terms like democracy, civil rights, and citizenship into their vocabulary. This was made explicit in a document circulated by al-Ikhwan in 1995 endorsing political pluralism (Norton 2005, p. 140). Typical leftist themes, such as social justice and anti-imperialism, were regularly used in Islamist pamphlets as well (Al-Ali 1999, p. 139). An Islamist feminist discourse, distinctive from that of the West, was also formulated in the late 1990s (Abdo 2000, p. 147; Mahmood 2005). In short, Islamists tried to convey the notion that the values of freedom and justice would be achieved under Islamist rule.

Furthermore, al-Ikhwan recognized that if it were to form alliances with other subordinated groups, its worldview would have to revolve around cultural rather than political issues (Ibrahim 1999, p. 41). Youssef al-Qaradawi, a highly revered cleric associated with al-Ikhwan, advocated the view that "societies are established on cultural values," and that only after these values have been sufficiently cultivated could one discuss politics. Muhammad al-Ghazzali, another influential scholar and supporter of al-Ikhwan, argued that because colonialism "deformed [Muslim] personalities," the struggle to reclaim Muslim culture must override petty political conflicts. Fahmy Huwaidi, a celebrated newspaper columnist close to al-Ikhwan, warned that imposed Westernization was the greatest threat to Muslim society (Baker 2003, pp. 42, 7-10). Similar views were expressed by Islamist intellectuals such as Muhammad 'Abd al-Qudus, al-Ikhwan's press syndicate representative, 'Abd al-Wahhab al-Messiri, the renowned Islamist professor, and Mohammed 'Immara, the prolific Islamic historian (Abaza 1999, pp. 95-101). So in order to 
attract social allies, Islamists articulated their worldview "in language akin to Huntington's 'clash of civilizations', whereby mobilization was viewed as a response to insidious Western desires to undermine the culture of Muslim societies" (Wiktorowicz 2004, p. 7).

This skillful incorporation of leftist, liberal, and feminist concerns, in addition to underscoring the danger posed by the Westernization of Islamic culture drew some of Egypt's most prominent intellectuals closer to Islamism (Esposito 1999, pp. 51-52). Gamal al-Ghitani, a nationalist novelist and editor of a prestigious literary journal, proclaimed that his primary concern was to protect Islamic culture from a civilization that was "acting stupidly." Son'allah Ibrahim, the famous Marxist novelist, focused a couple of his recent novels on the moral degradation of the West and its constant persecution of Muslims. Diaa' Rashwan, one of Egypt's leading political analysts, called for unity against the "cultural war" to subdue Muslims. Muhammad Salmawi, liberal playwright and newspaper editor, blamed the West for giving secularism "a bad name in Egypt" (Remnick 2004, pp. 7-9). In addition, interviews conducted with thirteen artists and critics reflected a general affiliation with the Islamist worldview (Fakhri 2001).

The regime did not lose any sleep over al-Ikhwan's cultural campaign. As long as Islamists remained within the world of culture and ideas, they did not pose a political threat. As a matter of fact, al-Ikhwan's prioritization of culture over politics was music to the rulers' ears. Encouraging Egyptians to direct all efforts towards cultural revival and personal piety diverted them, at least temporarily, from defying political authority in any meaningful way. It was the structural advances of al-Ikhwan that troubled the regime.

Although Islamists believed in the power of their ideas, they understood that ideas disseminate through socialization structures. Al-Ikhwan therefore targeted what Gramsci referred to as the "multilayered associations and voluntary groups" that constitute civil society: political parties, associations, educational and religious institutions, the media, and the courts (Fontana 2008, p. 93). To optimize its ability to capture these structures, al-Ikhwan did not rely solely on its members, but on a loosely affiliated body of activists comprising various social movements, informal networks, and intellectuals who subscribed to Islamism. ${ }^{13}$ According to 'Essam al-'Erian, the head of al-Ikhwan's political bureau, Egypt's security-dominated environment pushed the movement towards decentralization. Al-Ikhwan therefore coordinated and financed independent efforts to control and utilize socialization structures (Al-'Erian 2009, pp. 7-8). I devote the remainder of this section to how Islamists penetrated each of these structures.

Political parties Theoretically, political parties are supposed to represent the interests of particular social groups. In Egypt, for example, liberal parties, such as al-Wafd and al-Ahrar, represented the rural bourgeoisie and its industrial successors, while the socialist al-Tagammu' and al-'Amal parties represented the workers and, to

\footnotetext{
${ }^{13}$ Bayat described Egyptian Islamism as a "complex web of dispersed and heterogeneous organizations, activities, and sympathies around a distinct core embodied in the ... Muslim Brotherhood" (2007, p. 137). Abdo regarded al-Ikhwan as the "convenient vehicle" through which Islamist-leaning Egyptians strive to create the Islamic society they desire (2000, p. 75).
} 
a lesser extent, the peasants. But as Gramsci reminded us, during times of political stagnation, parties become detached from their social bases; they become "mummified and anachronistic," incapable of adapting politically. The party becomes "a compact body, which stands on its own and feels itself independent of the mass ... voided of its social content and left as though suspended in mid-air" (1971, pp. 210-211).

When the Egyptian regime established, funded, and handpicked leaders for political opposition parties in the late 1970s, it had intended for these parties to remain politically sterile. But instead, the opposition parties' weakness and utter dependence on the state tempted them to flirt with the increasingly popular Islamist ideology (Shukrallah 1989, p. 48). Capitalizing on the "deep Islamic sentiments of the populace," some of these parties formed electoral alliances with al-Ikhwan (Auda 1993, p. 399). ${ }^{14}$ In return for Islamist votes, parties offered al-Ikhwan a legal venue into parliament.

Al-Ikhwan's first alliance was with the liberal al-Wafd in 1984. The electoral alliance captured $15 \%$ of the vote (58 seats) and became the largest opposition group in parliament (Norton 2005, p. 136). Ignoring al-Wafd's strong secular roots, 'Omar al-Telmessani, the then Supreme Guide of al-Ikhwan, declared that Wafdists should commit themselves to legislating according to God's law. This caused a split within the ranks of the party, eventually leading to the termination of the alliance (Shukrallah 1989, p. 30). In 1987, al-Ikhwan negotiated another alliance with the socialist al-'Amal. But instead of a temporary alliance, al-'Amal ceded to a "Muslim Brethren takeover." The merger attracted another odd member: the liberal al-Ahrar, which suffered from an almost complete lack of popular support (Shukrallah 1989, pp. 24, 38). The new Islamist-led tripartite alliance won $17 \%$ of the vote (60 seats), again leading opposition in parliament (Norton 2005, p. 136). Through these alliances, Islamist ideas permeated election campaigns, opposition newspapers, hearing committees, and parliamentary sessions. By the end of the 1980s, "Islamists became the leading opposition force in parliament" (Wiktorowicz 2004, p. 74).

This development caught the regime by surprise. But even after sabotaging these alliances (as discussed below), al-Ikhwan continued to win votes. In the 2000 elections its candidates ran as independents and won 17 seats - more than the total number of seats won by all opposition parties combined - and became once more the largest opposition block in parliament (Norton 2005, p. 138). A more striking victory occurred in the 2005 elections, when al-Ikhwan secured 88 seats, more seats than those won by any opposition party since the 1952 coup.

Educational facilities Gramsci warned that at the hands of rulers, schools and universities become factories for producing technocrats and professionals, primed for either serving the state or pursuing a narrowly individualistic career. In other words, if educational institutions are not permeated by political ideologies they turn

\footnotetext{
${ }^{14}$ In their electoral campaigns, al-Ikhwan used slogans like "Islam is the solution" and "God is our objective, the Prophet our leader, and al-Qur'an our constitution," in addition to the powerful dictum: "Give your vote to Allah, give it to the Muslim Brotherhood" (Wickham 2002, p. 92). Islamists were also better funded, securing considerable publicity for their candidates through massive deployments of posters and banners in cities and villages (Ebeid 1989, pp. 43-44).
} 
out nothing but "apolitical national cadres" (1971, p. 228). A counterhegemonic movement must influence curriculums and the overall organization of the education process. Teachers must use their position to turn students against the ruling worldview (Gramsci 1971, pp. 26, 35-36).

Schooling therefore provided another medium for Islamists to circulate their views. Since the 1980s, most Arabic and religion teachers were affiliated with alIkhwan. A 1997 study of 354 elementary education teachers revealed that $86 \%$ of them were Islamists. In fact, al-Ikhwan dominated the Teacher Training College, which produced future schoolteachers. Accordingly, classes often turned into sessions for Islamist indoctrination (Bayat 2007, pp. 170-171).

Al-Ikhwan also controlled university students' unions, which were the "strongest political force available for the expression of students' discontent" (Shukrallah 1989, p. 79). Throughout the 1980s, Islamists dominated unions in Cairo, Alexandria, Asyut, Minya, and other major universities (Esposito 1999, p. 53). Since 2000 they became active in the American University in Cairo (AUC), traditionally considered a bastion of secular elites (Bayat 2007, p. 147). When the state restricted Islamist activity on campuses (discussed below), al-Ikhwan formed shadow unions-labeled Free Students' Unions - in 2006 (IHRC, May 2007).

Professional syndicates For Gramsci professional syndicates were the prototype of civil society organizations (Fontana 2008, p. 93). That is why some considered alIkhwan's control of most of Egypt's professional syndicates as the movement's "most stunning performance" (Ibrahim 1999, pp. 32-33). In less than a decade, "twenty-one professional syndicates, encompassing about 2.5 million members, fell into their hands." The signal success was in the Medical Syndicate in 1986, followed by the Engineering, Pharmacist, and other syndicates. But the development that reportedly "stunned Mubarak" was their securing of $75 \%$ of the vote at the Lawyers Syndicate during the 1992 elections (Norton 2005, p. 138). The latter was always regarded as a "citadel of secularism" (Abdo 2000, p. 95). Islamists victories in most syndicates continued well into $2007 .^{15}$

The media Little needs to be said about the media's central role in shaping worldviews. Gramsci emphasized that a counterhegemonic movement must never tire of "repeating" its ideas; "repetition is the best didactic means for working on the popular mentality" (1971, p. 340). The media-which for Gramsci connoted "the whole complex system devised to construct and generate, to communicate, store, and retrieve, knowledge and information"-was all about indoctrination through repetition (Fontana 2009, p. 83). Gramsci also recognized that preventing competing views from gaining currency was as important as promoting one's own ideas. Despite Gramsci's aversion to police-like restrictions, he advocated: "fixing the limits of freedom of discussion and propaganda" for the overall benefit of the counterhegemonic strategy (1971, p. 341).

Islamists became very active in cultural production (Wickham 2002, p. 101). They published books, newspapers, and voiced their opinions through radio and television. Gulf patrons subsidized Islamist publications, making them "inexpensive,

$\overline{{ }^{15} \text { For more details see chapters } 3}$ and 4 in Schlumberger (2007). 
attractively printed, and accessible" (Eickelman 2005, pp. 44-45). Al-Ikhwan's periodical, al-Liwa', increased in circulation from 35,000 in 1987 to 95,000 in 1991 (Wickham 2004, pp. 102, 240). In addition, Islamism became entrenched in the public media: radio and television were made to open and close with Qur'anic recitations, the call to prayer interrupted programs, and Islamist intellectuals became frequent guests on various talk shows (Price 1999, p. 49; Yohannes 2001, p. 253). Islamists also made the most use of new technologies. Islamist Internet sites (such as Islam-online) became extremely popular. Many satellite channels (such as Iqra) were devoted to promoting Islamism; others aired programs sympathetic to Islamist views (such as al-Shari 'a wal-Haya on al-Jazeera) (Hefner 2005, p. 12; Eickelman 2005, pp. 37-49). Even music was not immune to the "rise of pious passion," as leading pop singers (like 'Amr Diyab and Muhammad Mounir) began to perform religious songs (Bayat 2007, p. 148).

Religious establishment Considering the influence of Catholicism in Italy, it is not surprising that Gramsci was fairly mindful of the unique power of religion in maintaining and disrupting cultural hegemony (Fontana 2008, p. 95). He acknowledged that for the great majority "the relationship between common sense and religion is much more intimate than that between common sense and philosophical systems of the intellectuals." In a religious society, citizens simply believe that so many "like-minded people cant' be wrong." Opposition movements must win the dominant religious institution to their side because during the struggle for hegemony religion rarely loses its sway over believers (Gramsci 1971, pp. 420, 338-340). "The strength of religions," Gramsci concluded, "has lain, and still lies, in the fact that they feel very strongly the need for the doctrinal unity of the whole mass of the faithful" (1971, p. 328).

Religion was of course Islamists' strongest asset. The central religious institution in society was "the mosque." Out of 46,000 mosques in 1981, the Ministry of Religious Endowments administered only 6,000. By 1993, the number increased to 170,000 , and the ministry operated only 30,000 (Yohannes 2001, p. 261). Mosques below the state's radar became fertile fields for spreading Islamism. In the course of ritual activities, information was communicated, new members were recruited, and worldviews were formulated (Wickham 2002, p. 53). These "activist mosques" promoted "a feeling of belonging and an intimacy with peers based on shared commitments and routines" creating "powerful pressures for social conformity" (Wickham 2004, pp. 233-234). Mosques were usually associated with popular sheikhs (like Mitwali al-Sha'rawi and Abd al-Hameed Kishk) who swayed the middle and lower classes. For the upper class, modernstyled sheikhs (like 'Omar 'Abd al-Kafi and "Amr Kahled) carried Islamism to the comfort of "private homes, clubs, and the stylish mosques of posh neighborhoods." The "active piety" preached at these mosques encouraged believers to take the initiative in converting others to the Islamist worldview (Bayat 2007, pp. 149151). In other words, the desire to become "better Muslims" created elaborate social networks "setting in motion a trickle-down effect" throughout society (Abdo 2000, p. 140).

Islamists also made inroads into the official religious establishment. Al-Ikhwan had frequently criticized the "civil servant" attitude of al-Azhar clerics (Abdo 2000, 
p. 49). ${ }^{16}$ But starting form the $1980 \mathrm{~s}$, many Azhar jurists began to advocate Islamism in public (Zubaida 2005, pp. 164-165). The most noted example is how they censored dozens of novels, movies, and academic works at the behest of al-Ikhwan (Yohannes 2001, p. 266). Unlike their subservient predecessors, these new rebellious clerics "formed relationships with those involved in the political Islamic movement" (examples include Isma'il Sadiq al-'Adawy, Sayyed 'Askar, Gamal Qutb, and Yahya Isma'il). There were also clerics (notably al-Qaradawi and al-Ghazali) who went as far as officially joining al-Ikhwan at some point (Abdo 2000, pp. 31-51).

Court system Through his elaboration of how hegemony operates, Gramsci offered "profound insights about the law's ability to induce submission to a dominant worldview" (Litowitz 2001, p. 516). Because achieving hegemony involves promoting certain behaviors and eliminating others, rulers inevitably resort to the "repressive" function of the law (Gramsci 1971, p. 247). The legal system is "hegemonic in the Gramscian sense" because it induces "passive compliance" throughout society. In that sense, laws are important because they perpetuate "the status quo and its attendant inequalities, oppressions, and disaffections," and mystify the coercive side of politics (Litowitz 2001, pp. 517-518). That is why Gramsci believed that courts "provide room for counter-hegemonic struggles in the form of litigation that challenges key components of the legal system" (Litowitz 2001, p. 549).

Islamists employed existing laws to their benefit. Most notably, they used al-hisba law ${ }^{17}$ to censor intellectual and artistic works that promoted values contrary to theirs. Islamist lawyers (such as Youssef al-Badri) sued journalists, writers, artists, and even actresses and dancers. In 1996 alone, Islamists brought 60 hisba suits against a host of targets and won most of them (Yohannes 2001, p. 257). Examples include a 1991 case brought to court by the Islamist professor Mustafa al-Shaka'a against broadcasting Fawazir Ramadan, a television show which featured female entertainers performing "Westernized singing and dancing." A second incident occurred in 1994, when al-Ghazzali attacked the television series Al-'Aila for expressing heretical views; thus triggering a court case that sanctioned religious censorship on cultural products (Baker 2003, pp. 53-76). There were also lawsuits filed against secular intellectuals, such as Saad Eddin Ibrahim, Chair of the Sociology Department at AUC, who was accused of defaming Islam (Rose al-Youssef, January 15, 2005), and Nawal al-Sa'dawi, the feminist novelist and literature professor, who was sued for criticizing the spread of al-hijab (veiling) among Egyptian females (October, January 16, 2005).

To summarize: although Islamists were hardly familiar with Gramsci's writings, al-Ikhwan and its affiliated activists adopted a strategy quite similar to the one he proposed. They successfully articulated and promoted through various socialization structures a worldview that effectively undermined that of the rulers. As the regime's secular worldview began to lose hegemony, Islamists should have been able to mobilize the masses against their rulers and eventually gain political power. What happened

\footnotetext{
${ }^{16}$ An oft-cited exemplar of this behavior is that when Nasser was threatening war against Israel, al-Azhar clerics asserted that the conflict with Zionism was a holy struggle; but when Sadat and Mubarak negotiated peace with Israel, al-Azhar shifted to how Islam preaches peace (Abdo 2000, p. 31).

17 This is a law allowing Muslims to bring to court those who, in their view, offend Islam.
} 
instead was that the regime - without contesting the Islamist worldview-aborted that move by effectively depriving al-Ikhwan from further access to socialization structures.

\section{Countering counterhegemony: escalating regime repression}

Reaction to the Islamist counterhegemonic strategy was typical of the Mubarak regime: "slowly, indirectly, and subtly, until a sledgehammer suddenly comes down" (Abdo 2000, p. 74). The parliamentary election of 1990 signaled the beginning of the end of the regime's toleration of Islamists. Electoral Law 206 of 1990 redrew voting districts in favor of the candidates of the regime and revoked judicial oversight. The 1990 elections were marked by fraud, intimidation, and an "unprecedented level of violence;" leading some to describe it as the worst in Egyptian history (Norton 2005, pp. 136-141; Wiktorowicz 2004, p. 74). In the 1995 elections, Islamist candidates were preemptively detained to prevent them from running altogether. The single Islamist that made it to parliament was removed by the regime a few months later on account of his "membership in an illegal organization" (Kassem 2004, p. 63). Al-'Amal party, al-Ikhwan's main collaborator, was suspended, and from 1998 to 2005 , the regime froze the activities of seven other political parties that could have been potential allies for Islamists (Bayat 2007, p. 144). ${ }^{18}$

To counter the Islamist foothold in professional syndicates, the regime issued Law 100 of 1993, which imposed stringent conditions on the electoral process. An almost identical law was applied to student union elections. And in 1994, the Universities' Law was amended to end the practice of electing deans and chairs, and instead having them appointed by the state (Norton 2005, p. 139). In May 1995, police forces occupied the Engineers Syndicates' headquarters, detained dozens of activists, and placed the syndicate under hirasa (state guardianship). This was repeated in the Lawyers' and other syndicates. Court rulings against hirasa were ignored. Troops were stationed around university campuses, and armed security guards "became a permanent fixture" of university life (Abdo 2000, pp. 79, 105-116). The regime also passed several draconian laws to repress civil associations, such as Presidential Decree 4 of 1992, which denied any association the right to accept foreign funds without government permission, and Law 84 of 2002, which granted the Ministry of Social Affairs the right to revoke the license of any civil association that got involved in politics. The regime closed down hundreds of private mosques, took over 60,000 mosques from Islamists, and required preachers to obtain a government permit before conducting sermons (Bayat 2007, p. 144). In 1996, Hussein Tantawi, a regime loyalist, was appointed Grand Sheikh of al-Azhar to realign the religious establishment with the ruling worldview (Abdo 2000, p. 62).

Steps to disarm civil courts began with Presidential Decree 370 of 1992 referring cases against Islamists to Military Courts that do not grant the right of appeal (Abdo 2000, p. 184). In June 1995, the government started a series of detentions and military trials of leading Ikhwan activists. The movement's headquarters and over five thousand of its offices were raided. From 1993 to 1995 more than a thousand Islamist activists were detained (Bayat 2007, pp. 144, 171), and between 1995 and

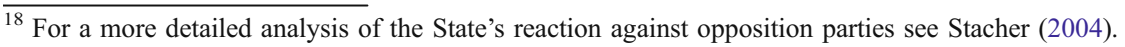


2007, ninety-five of al-Ikhwan's leaders were tried by military tribunals and sent to prison (IHRC, May 2007). In 1998 the government passed a law prohibiting individuals from filing hisba petitions. All petitions were to be referred to the state prosecutor to decide which would be pursued (Bayat 2007, p. 172). To preempt a violent Islamist reaction, the Penal Code and the State Security Law were amended via Law 97 of 1992, which extended the definition of terrorism to any action that disturbed public order (even by causing a traffic jam) or obstructed the work of state authorities (Kassem 2004, p. 155).

After isolating the movement socially, the regime shifted to a strategy aimed at its gradual eradication. In December 2006, Mubarak prompted parliament to amend thirtyfour articles of the Constitution: prohibiting religiously-based politics (article 5), revoking judicial supervision over all public elections, and replacing Emergency Laws with a new Anti-Terrorism Law, which gives security officers a carte blanche in dealing with Islamists (IHRC, May 2007). A few months later, in February 2007, Mubarak described al-Ikhwan - for the first time since the movement's establishment-as a "direct threat to Egyptian national security" (Al-'Anani 2009, p. 4). In April 2008, a militarily tribunal ordered the confiscation of one third of al-Ikhwan's financial assets (several million dollars), closed down its major economic projects, and sentenced its Deputy Supreme Guide, along with twenty-four of its chief strategists to prison. During 2009, the police detained 320 middle and top-level Ikhwan leadersparalyzing the movement's capacity to communicate with its members or coordinate its strategy (Al-'Anani 2009, p. 2). One indicator of how badly the movement was hit was that out of ten thousand Ikhwan candidates not a single one got elected during the 2008 municipal elections and not a single member made it to parliament in 2010 (Al-Galad et al. 2009: Al-Masry Al-Youm, October 24, 2009).

The head of al-Ikhwan's political bureau described this as the most critical phase in the movement's history, confessing that hard-hitting state repression has crippled the organization to the point where the leadership has lost its ability to strategize and many members began to lose confidence in their leaders. In his assessment, alIkhwan can no longer function in this full-fledged "police state" (Al-'Erian 2009, pp. 1-2, 9). Similarly, Mahdi 'Akif, al-Ikhwan's Supreme Guide decried: We have become hostages in a "country ruled by the security establishment...the security controls everything" (Al-Masry Al-Youm, October 24, 2009). "Akif admitted that it was State Security that fixed al-Ikhwan's 2005 electoral victory, detailing in a recent interview how security representatives asked him to run in 150 designated electoral districts and promised to support the movement's candidates (Al-'Anani 2009, p. 5; Al-Masry Al-Youm, October 24, 2009). By manipulating al-Ikhwan, the regime successfully outmaneuvered US pressures to democratize by demonstrating through the ballot box that the only alternative to Mubarak was Islamism. And by admitting the fact that security officials orchestrated the movement's greatest electoral victory, the Supreme Guide unwittingly demoralized Islamists further.

\section{Analysis: the limits of counterhegemonic strategies}

What was the impact of Islamization on Egypt in the past 25 years? Islamists succeeded in transforming popular consciousness and winning the support of a 
sizable majority for their worldview. This was not only evident in election results, whether parliamentary or associational, but also observed in the changed social attitudes towards Islam. ${ }^{19}$ Bayat described this change as "an Islamic 'revolution by stealth" (2007, p. 138). Abdo, in turn, referred to it as "a quiet revolution" that posed a definite danger to the regime (2000, pp. 25, 43). These metaphors notwithstanding, the fact is: Islamists have not come to power, nor do they appear anywhere close.

What happened instead was that the ruling regime employed the state's coercive and punitive organs to abort al-Ikhwan's strategy on every level: it blocked its access to civil society, it disrupted its activists' networks, and it dealt decisive blows to the organization itself. So without having to undermine the popularity of the Islamist worldview, the regime shackled the structures it spread through. It became clear that the Islamist counterhegemonic strategy was not only incapable of overthrowing the rulers, but that the very capacity to execute such a strategy depended on the regime's tacit consent.

Despite their social influence, Islamists stood helpless against regime repression. Ikhwan supporters were certainly not prepared to rush into a head-on clash with state institutions. The movement's attempt to provoke popular sympathy by presenting itself as a victim fell on deaf ears - the regime had effectively terrified society enough to turn away from al-Ikhwan (Al-'Anani 2009, pp. 3-5). The movement's only option was to adopt a "strategy of patience," hoping to weather the state's repressive campaign, counting on "time as the best remedy" (Al-'Erian 2009, p. 2-3). The Supreme Guide made it clear that al-Ikhwan would not be dragged into a violent confrontation with the regime under any circumstances (Al-Masry Al-Youm, October 24, 2009).

Al-Ikhwan's fear of confronting the regime became clear when it turned its back on the series of strikes organized by several advocacy groups (judges, professionals, university professors), along with workers, poverty stricken communities, and young bloggers. Without the backing of a major opposition movement, like al-Ikhwan, the strikes that took place between 2005 and 2008, culminating in a general strike on April 7, 2008, boiled down to narrow social demands (bonuses, promotion, bylaw amendments, and improved public services). Instead of capitalizing on the rising tide of public discontent with state corruption and inefficiency, al-Ikhwan's sole concern was not to provoke the regime any further (Al-'Anani 2009, p. 4).

This outcome was not surprising considering the decisive role of coercion in modern states. Poggi emphasized how the element of "fear"-one of the most compelling human emotions - has become central to maintaining political power in the modern world. Although ideology could at times inspire action, the political experience of the majority of citizens remains grounded in the "harsh reality of physical coercion." A regime's capacity to inflict or threaten to inflict physical damage on its subjects helps it invoke the "fear of pain, physical violation, forceful restraint or death" in the hearts of those who dare to oppose it (2001, pp. 30-31). This was encapsulated in Poulantzas's pointed critique of Gramsci: "Only too often

\footnotetext{
${ }^{19}$ Nowadays, "ask any Egyptian and he will say that the years the country muddled through secularism were the exception," and that Islamic doctrines, which "encompass all aspects of man's existence," have guided the country since its conversion to Islam and should continue to do so (Abdo 2000, p. 25).
} 
does emphasis on the state's role in ideological relations lead to underestimation of its repressive functions. By repression should be understood first and foremost organized physical violence in the most material sense of the term: violence to the body" (2000, p. 29).

One could find further confirmation of this view in Chorley's assessment of the necessary conditions for radical political change. Chorley insisted that, despite the democratic pretensions of many modern states, historical experience sustains the inconvenient conclusion that "force forms the foundation of society as we know it" ([1943] 1973, pp. 9-11). Along the same line, Anderson asserted that in the final contest over political power, the coercive apparatus of repression "inexorably displaces the ideological apparatuses" of the state (1976, p. 76). In short, opposition movements cannot afford to focus solely on gaining popular support. Assuming that the objective is to achieve real political change, the first task of opposition leaders is to determine how to confront the coercive institutions that will inevitably be instructed to repress them.

How could this outcome help us assess Gramsci's counterhegemonic thesis? I argue that this case study does not render Gramsci's model entirely ineffective, but rather provides valuable insights into the limitations of the widespread cultural reading of Gramsci. What is so problematic about this reading is that it does not really explain how "ideas become practical forces" (Fiori 1970, p. 93). Bayat pointed out that those who apply counterhegemonic strategies soon discover that "discourse is not power unless it is given material force" $\left(2007\right.$, p. 6) ${ }^{20}$ In fact, the only reason why Gramsci believed that counterhegemony would eventually transcend the boundaries of civil society and spill over into the political sphere was that ideas have the power to inspire action (Boggs 1984, p. 158).

It is clear that Gramsci could not have overlooked the role of coercion. Claiming the contrary is simply untenable considering both Gramsci's writings and practice. Anderson made it clear that Gramsci never relinquished the "ultimate necessity for violent seizure of State power." Anderson even hinted at the possibility that Gramsci was too aware of the realities of political coercion and violence in that "he seems to have taken them so much for granted that they scarcely ever figure directly in his discourse at all" (1976, pp. 69, 47). Also, we cannot dismiss the fact that Gramsci was not merely a leftist theoretician; he was one of the relatively hawkish leaders of the Partito Communista Italiano (PCI), who spent the last decade of his life in prison because of his militancy. Gramsci was particularly weary of mass-based parties that postponed political action indefinitely and demanded "no other political function [of their followers other] than loyalty." Gramsci resented these parties for doing little more than entertaining their members "by means of moralizing sermons, emotional stimuli, and messianic myths of an awaited golden age, in which all present contradictions and miseries will be automatically resolved and made well"' (1971, pp. 149-50).

This does not mean that Gramsci's doctrine was free from tensions. According to Anderson, despite his appreciation of the contingencies of force, Gramsci's "strategic

\footnotetext{
${ }^{20}$ Bayat resolved this dilemma by suggesting that it is possible to "socialize states and political elites into society's sensibilities, ideals, and expectations" from below, only if opposition movements could perfect the "art of presence in harsh circumstances" and maintain its social space (2007, pp. 14, 201). It is clear from the Egyptian case that this was not sufficient.
} 
formula ... fails to integrate them" (1976, p. 69). It is true that Gramsci was aware that the coercive machine of the state could never be undermined through an exclusively culture-based counterhegemonic strategy; that it could only be broken by "preemptive counter-coercion" (1976, p. 76). But what might have eluded Gramsci, Anderson concluded, was that the necessarily "sudden and volcanic nature of revolutionary situations ... can never be stabilized for long and therefore need the utmost speed and mobility of attack if the opportunity to conquer power is not to be missed" (1976, pp. 71-75). Ernest Mandel was similarly skeptical regarding the possibility of "maintaining a hegemonic alliance through a long drawn-out process of a war of position." In his view, "a strategy that seeks to capture civil society before any war of maneuver against the state ends up yielding to reformism ... revolutionary struggle [can only unfold] quickly and decisively" (quoted in Joseph 2002, p. 41).

So how exactly did those who adopted a narrowly cultural version of Gramsci's strategy expect to bypass the problem of state coercion? How could the contradiction between the worldview of the rulers and that of the ruled resolve itself politically? How could a change in the world of ideas trigger a corresponding change in the world of political reality? Was the ruling regime supposed to step down or simply "wither away" under cultural pressures?

Adamson explained that opposition intent on achieving cultural hegemony assumed a situation where the state was not so pervasive as to be able to check the rise of oppositional forces, and at the same time sufficiently dependent on its hegemony so that an alternative hegemony would effectively paralyze it. Adamson concluded that this has become a very unlikely situation in the modern world, where the capacity of the state to block counterhegemonic strategies is "unprecedentedly high" (1980, pp. 179, 239). That was why Boggs predicted that an opposition movement that focused on a strictly cultural strategy would inevitably find itself overwhelmed by the state's coercive institutions. He dismissed the belief that a long cultural struggle would "gradually erode and supersede the prevailing, seemingly indestructible institutions of state power" as hopelessly utopian (1977, p. 383).

This critique should not imply that a cultural reading of Gramsci is utterly useless. The consensual conception of power, which lies at the heart of this reading, offers important insights into the cultural aspects of modern state power. While a cultureoriented counterhegemonic strategy might not lead to the conquest of political power, it could secure social support for a new regime, should it succeed in coming to power through other means. A counterhegemonic strategy could perform the important function of uniting opposition and carrying it to the brinks of political powerthrough it will not shift the balance of power between the opposition and the rulers. What is clear therefore is that while cultural hegemony mystifies political power, the dominance of those who control the state-stripped from all pretensions - ultimately rests on brute force.

A cursory look at examples of Islamists who came to power supports this conclusion. Successful Islamist movements combined culture-based mobilization with purposive strategies aimed at neutralizing the state's coercive power. In Pakistan (1977) and the Sudan (1989), they allied with successful coup leaders; in Turkey (2002), they infiltrated the police force and engaged in rigorous negotiations with the military; and in Iran (1979), they capitalized on the Shah's alienation of his 
own security and military institutions. Still in other cases (Afghanistan 1989; Lebanon 1989; Somalia 1991; Iraq 2003; Palestine 2006), Islamists enhanced their political leverage only after war and civil strife had paralyzed the state's central coercive organs. Needless to say, these are all instances where the political structure or geopolitical context provided Islamists with a maneuvering space; voluntarist strategies - no matter how skillfully executed-could hardly work if the state's coercive capacity remained intact.

Acknowledgments I am indebted to Professor Rogers Brubaker for his extensive comments and suggestions on several drafts of this article, and to Professors Michael Mann, William Roy, and Perry Anderson for their guidance and support. I also want to thank the Editors and reviewers of Theory and Society for their valuable comments. An earlier version of this article was presented at the Middle East Studies Association annual meeting, Washington D.C., 2008.

Open Access This article is distributed under the terms of the Creative Commons Attribution Noncommercial License which permits any noncommercial use, distribution, and reproduction in any medium, provided the original author(s) and source are credited.

\section{References}

Abaza, M. (1999). Tanwir and Islamization: Rethinking the struggle over intellectual inclusion in Egypt. In E. Hill (Ed.), Discourses in contemporary Egypt: Politics and social issues (pp. 85-117). Cairo: American University in Cairo Press.

Abdel Raouf, A. M. (1989). Arghamt Farouk 'ala al-tanazul 'an al-'arsh. Cairo: Al-Zahraa Lel-'Ilam Al-Arabi. Abdo, G. (2000). No God but God: Egypt and the triumph of Islam. New York: Oxford University Press.

Adamson, W. (1980). Hegemony and revolution: A study of Antonio Gramscis political and cultural theory. Berkeley: University of California Press.

Al-Ali, N. S. (1999). A mirror of political culture in contemporary Egypt: Divisions and debates among women activists. In E. Hill (Ed.), Discourses in contemporary Egypt: Politics and social issues (pp. 118-143). Cairo: American University in Cairo Press.

Al-'Anani, K. (2009). Al-nizam wa al-Ikhwan fei masr: hal tataghair qawa'id al-lu'ba? (The regime and al-Ikhwan in Egypt: Will the rules of game change?). http://www.aljazeera.net/NR/exeres/ D25AB80C-7A5B-41B9-893E-23A8FFCE1727.htm.

Al-'Awa, S. M. (2006). Al-Jama'a al-Islamiya al-musalaha fei misr, 1974-2004. Cairo: Al-Shorouk Al-Dawliya.

Al-Banna, H. (1948). Majmu'at Rasa'il al-Imam al-Shaheed Hassan al-Banna. Cairo: Al-Maktaba al-Tawfeeqia.

Al-'Erian, 'E. (2009). Al-athar al-ganibiya lel hamla al-bolisiya 'ala al-Ikhwan (The side effects of the security campaign against al-Ikhwan). http://islamyoon.islamonline.net/servlet/Satellite?c=ArticleA_ C\&cid=1256034032934\&pagename=Islamyoun/IYALayout.

Al-Galad, M., Al-Masry C. F., \& Al-Khatib, A. (2009). Mahdi 'Akef fei awal hiwar sahafi ba'd azmat alinsihab (Mahdi 'Akef in his first newspaper interview following the withdrawal crisis). Al-Masry AlYoum, 24, October, p. 11.

Anderson, P. (1976). The antinomies of Antonio Gramsci. New Left Review, 100(1), 5-78.

Auda, G. (1993). The Islamic movement and resource mobilization in Egypt: A political culture perspective. In L. Diamond (Ed.), Political culture and democracy in developing countries (pp. 379-410). Boulder: Lynne Rienner Publishers.

Baker, R. W. (2003). Islam without Fear: Egypt and the New Islamists. Cambridge: Harvard University Press. Bayat, A. (2007). Making Islam democratic: Social movements and the Post-Islamist turn. Stanford: Stanford University Press.

Billings, D. B. (1990). Religion as opposition: a Gramscian analysis. The American Journal of Sociology, 96(1), 1-31.

Boggs, C. (1977). Revolutionary process, political strategy, and the dilemma of power. Theory and Society, 4(3), 359-393. 
Boggs, C. (1984). The two revolutions: Gramsci and the dilemmas of western Marxism. Cambridge: South End Press.

Burke, E. III, \& Lapidus, I. (Eds). (1988). Islam, politics, and social movements. Berkeley: University of California Press.

Burns, G. (1996). Ideology, culture, and ambiguity: the revolutionary process in Iran. Theory and Society, 25(3), 349-388.

Butko, T. J. (2004). Revelation or revolution: a Gramscian approach to the rise of political Islam. British Journal of Middle Eastern Studies, 31(1), 41-62.

Chorley, K. ([1943] 1973). Armies and the art of revolution. Boston: Beacon Press.

Ebeid, M. M. (1989). The role of the official opposition. In C. Tripp \& R. Owen (Eds.), Egypt under Mubarak (pp. 21-52). London: Routledge.

Eickelman, D. F. (2005). New media in the Arab Middle East and the emergence of open societies. In R. W. Hefner (Ed.), Remaking Muslim politics: Pluralism, contestation, democratization (pp. 37-59). Princeton: Princeton University Press.

Eickelman, D., \& Piscatori, J. (1996). Muslim politics. Princeton: Princeton University Press.

Esposito, J. L. (1999). The Islamic factor. In P. Marr (Ed.), Egypt at the crossroads: Domestic stability and regional role (pp. 47-64). Washington: National Defense University Press.

Fakhri, M. (2001). Men yahkum Misr ba'd Mubarak? Cairo: Publishing Rights Reserved to Author.

Fiori, G. (1970). Antonio Gramsci: Life of a revolutionary. New York: Schoken Books.

Fontana, B. (2008). Hegemony and power in Gramsci. In R. Howson \& K. Smith (Eds.), Hegemony: Studies in consensus and coercion (pp. 80-106). New York: Routledge.

Fontana, B. (2009). Power and democracy: Gramsci and hegemony in America. In J. Francese (Ed.), Perspectives on Gramsci: Politics, culture and social theory (pp. 80-96). New York: Routledge.

Foran, J. (2005). Taking power: On the origins of third world revolutions. New York: Cambridge University Press.

Gohar, S. (1976). Al-Samitun Yatakalamun (The Silent Speak-out). Cairo: Al-Maktab al-Misri al-Hadith.

Goldstone, J. (1991). Ideology, cultural frameworks, and the process of revolution. Theory and Society, 20 (4), 405-453.

Gramsci, A. (1971). Selections from the prison notebooks. New York: International Publishers.

Gramsci, A. (1994). Pre-prison writings. New York: Cambridge University Press.

Gramsci, A. (2000). In D. Forgacs (Ed.), The Antonio Gramsci reader: Selected writings 1916-1935. New York: New York University Press.

Hefner, R. W. (2001). Public Islam and the problems of democratization. Sociology of Religion, 62(4), 491-514.

Hefner, R. W. (2005). Introduction: Modernity and the remaking of Muslim politics. In R. W. Hefner (Ed.), Remaking Muslim politics: Pluralism, contestation, democratization (pp. 1-36). Princeton: Princeton University Press.

Howson, R. (2008). Hegemony in the preprison context. In R. Howson \& K. Smith (Eds.), Hegemony: Studies in consensus and coercion (pp. 16-32). New York: Routledge.

Howson, R., \& Smith, K. (2008). Hegemony and the operation of consensus and coercion. In R. Howson \& K. Smith (Eds.), Hegemony: Studies in consensus and coercion (pp. 1-15). New York: Routledge.

Hunt, L. (1984). Politics, culture, and class in the French revolution. Berkeley: University of California Press.

Huntington, S. (1968). Political Order in Changing Societies. New Haven: Yale University Press.

Ibrahim, S. E. (1999). The changing face of Egypt's Islamic activism. In P. Marr (Ed.), Egypt at the crossroads: Domestic stability and regional role (pp. 29-46). Washington: National Defense University Press.

Islamic Human Rights Commission. (2007). Prisoners of faith campaign pack: Muslim brotherhood. http:// www.ihrc.org.uk/file/PF070515KhairatAlShaterFinal.pdf.

Jones, S. (2006). Antonio Gramsci. New York: Routledge.

Joseph, J. (2002). Hegemony: A realist analysis. New York: Routledge.

Kassem, M. (2004). Egyptian politics: The dynamics of authoritarian rule. London: Lynne Rienner Publishers.

Kepel, G. (1984). Muslim extremism in Egypt: The Prophet and the Pharaoh. Berkeley: University of California Press.

Kepel, G. (2002). Jihad: The trial of political Islam. Cambridge: Belknap Press of Harvard University Press. Lears, J. T. J. (1985). The concept of cultural hegemony: Problems and possibilities. The American Historical Review, 90(3), 567-593. 
Litowitz, D. (2001). Gramsci, hegemony, and the law. Brigham Young University Law Review, 515-551. Machiavelli, N. ([1513] 2004). The Prince. New York: Pocket Books.

Mahmood, S. (2005). The politics of piety: Islamic revival and the feminist subject. Princeton: Princeton University Press.

Moaddel, M. (1993). Ideology as an episodic discourse: The case of the Iranian revolution. American Sociological Review, 57(3), 353-379.

Morton, A. D. (2007). Unravelling Gramsci: Hegemony and passive revolution in the global economy. London: Pluto Press.

Norton, A. R. (2005). Thwarted politics: The case of Egypt's Hizb al-Wasat. In R. W. Hefner (Ed.), Remaking Muslim politics: Pluralism, contestation, democratization (pp. 133-160). Princeton: Princeton University Press.

Poggi, G. (2001). Forms of power. Malden: Polity Press.

Poulantzas, N. (2000). State, power, socialism. New York: Verso Classics.

Price, D. E. (1999). Islamic political culture, democracy, and human rights: A comparative study. Westport: Praeger.

Remnick, D. (2004). Letter from Cairo: going nowhere. The New Yorker, 12-19, July.

Rubin, B. (2002). Islamic fundamentalism in Egyptian politics. New York: Palgrave Macmillan.

Salah, T. (2009). Abd al-Hamid al-Ghazaly mustashar murshid al-Ikhwan le Al-Masry Al-Youm: na'am 'aqadna safqa ma'a al-amn fei intikhabat 2005 (Abd al-Hamid al-Ghazaly, [political] advisor to alIkhwan's [supreme] guide, [declares] in Al-Masry Al-Youm: Yes, we made a deal with the security [apparatus] during the 2005 elections). Al-Masry Al-Youm, 29, October, p. 8.

Schlumberger, O. (2007). Debating Arab Authoritarianism: Dynamics and Durability in Nondemocratic Regimes. Stanford: Stanford University Press.

Selbin, E. (1997). Revolution in the real world: Bringing agency back in. In J. Foran (Ed.), Theorizing revolutions (pp. 123-136).

Sewell, W. (1995). Ideologies and Social Revolutions: Reflections on the French Case. Journal of Modern History, 57(1), 57-85

Shukrallah, H. (1989). Political crisis/conflict in post-1967 Egypt. In C. Tripp \& R. Owen (Eds.), Egypt under Mubarak (pp. 53-102). London: Routledge.

Skocpol, T. (1994). Revolutions in the Modern World. New York: Cambridge University Press.

Stacher, J. (2004). Parties Over: The demise of Egypt's opposition parties. British Journal of Middle Eastern Studies, 31, 215-33.

Vatikiotis, P. J. (1978). Nasser and his generation. London: Croom Helm.

Walzer, M. (1965). The revolution of the Saints: A study in the origin of radical politics. Cambridge: Harvard University Press.

Wickham, C. R. (2002). Mobilizing Islam: Religion, activism, and political change in Egypt. New York: Columbia University Press.

Wickham, C. R. (2004). Interests, ideas, and Islamist outreach in Egypt. In Q. Wiktorowicz (Ed.), Islamic activism: A social movement theory approach (pp. 231-249). Bloomington: Indiana University Press.

Wiktorowicz, Q. (2004). Introduction: Islamic activism and social movement theory. In Q. Wiktorowicz (Ed.), Islamic activism: A social movement theory approach (pp. 1-36). Bloomington: Indiana University Press.

Yohannes, O. (2001). Political economy of an authoritarian modern state and religious nationalism in Egypt. London: The Edwin Meller Press.

Zeidan, D. (2003). Radical Islam in Egypt. In B. Rubin (Ed.), Revolutionaries and reformers: Contemporary Islamist movements (pp. 11-12). Albany: State University of New York Press.

Zubaida, S. (2005). Law and power in the Islamic world. New York: I. B. Tauris.

\section{Further Reading}

Al-Awadi, H. (2004). In pursuit of legitimacy: The Muslim brothers and Mubarak, 1982-2000. New York: Tauris Academic Studies.

Al-Awadi, H. (2005). Mubarak and the Islamists: why did the 'honeymoon' end? The Middle East Journal, 59(1), 62-80.

Al-Banna, H. (1990). Al-Da'wah wal Da'iah. Cairo: Al-Zahraa Lil-'Ilam Al-Arabi.

Al-Qaradawi, Y. (2002). Al-Sahwa al-Islamiya min al-murahaqa ela al-rushd. Cairo: Dar al-Shorouk.

Al-Qaradawi, Y. (2003). Jeel al-nasr al-manshoud. Cairo: Maktabet Wahba.

Ansari, H. (1986). Egypt: The stalled society. New York: State University of New York Press. 
Basheer, T. (1999). The Egyptian state in transition. In P. Marr (Ed.), Egypt at the crossroads: Domestic stability and regional role (pp. 3-16). Washington: National Defense University Press.

Cook, S. (2007). Ruling but not governing: The military and political development in Egypt, Algeria, and Turkey. Baltimore: Johns Hopkins University Press.

Esposito, J. L., \& Voll, J. O. (2001). Makers of contemporary Islam. Oxford: Oxford University Press.

Gramsci, A. (1985). Selections from cultural writings. Cambridge: Harvard University Press.

Hafez, M. M., \& Wiktorowicz, Q. (2004). Violence as contention in the Egyptian Islamic movement. In W. Quintan (Ed.), Islamic activism: A social movement theory approach (pp. 61-88). Bloomington: Indiana University Press.

Ibrahim, S. E. (1996). Egypt, Islam, and democracy. Cairo: American University in Cairo Press.

Lahoud, N. (2005). Political thought in Islam: A study in intellectual boundaries. New York: RoutledgeCurzon.

Norris, P., \& Ronald, I. (2004). Sacred and secular: Religion and politics worldwide. New York: Cambridge University Press.

Singerman, D. (2004). The networked world of Islamist social movements. In Q. Wiktorowicz (Ed.), Islamic activism: A social movement theory approach (pp. 143-163). Bloomington: Indiana University Press.

Hazem Kandil is a Ph.D. Candidate in Sociology at UCLA. His work examines state institutions (primarily, the military and security organs) and religious movements, with a special focus on Egypt, Turkey, and Iran. He has taught at the American University in Cairo and has published elsewhere on the sociology of intellectuals, military sociology, developments in warfare, and international relations. 